\title{
Myxozoans infecting the sharptooth catfish, Clarias gariepinus in the Okavango River and Delta, Botswana, including descriptions of two new species, Henneguya samochimensis sp. n. and Myxobolus gariepinus sp. $\mathrm{n}$.
}

\author{
Cecilé C. Reed, Linda Basson and Liesl L. Van As
}

Department of Zoology and Entomology, University of the Free State, P.O. Box 339, Bloemfontein, 9300, South Africa

Key words: Myxozoa, Myxobolus, Henneguya, new species, taxonomy, Clarias, Botswana

\begin{abstract}
During a recent investigation of parasites infecting fishes from the Okavango River and Delta, Botswana (southern Africa) fourteen sharptooth catfish, Clarias gariepinus (Burchell, 1822) (Siluriformes: Clariidae) were examined for the presence of myxozoan infections. Results revealed the presence of two species of the genus Henneguya Thélohan, 1895 and one species of the genus Myxobolus Bütschli, 1882 infecting this fish host. Two of the sampled fish exhibited large plasmodia of Henneguya suprabranchiae Landsberg, 1987 in the cartilage of the accessory breathing organ, another two individuals were infected with $H$. samochimensis sp. n. plasmodia in the gills and another three individuals revealed an infection with Myxobolus gariepinus sp. $\mathrm{n}$. plasmodia in the ovaries.
\end{abstract}

The sharptooth catfish, Clarias gariepinus (Burchell, 1822) (Siluriformes: Clariidae) is probably the most widely distributed fish species in Africa, with many names such as C. mossambicus Peters, 1852 and $C$. lazera Valenciennes, 1840 being recognised as its junior synonyms (Skelton 1993). The economic importance of this fish species has increased greatly in recent years as a result of its extensive use in aquaculture (Skelton and Teugels 1992). Furthermore, natural populations of $C$. gariepinus form a staple diet for many subsistence farmers throughout the African continent. Coinciding with the growing economic value of this fish is the increased interest in its parasite loads and what effect they might hold for the aquaculture industry. One particular group of parasites, the myxozoans, is well known for the diseases they cause in commercially important fish hosts. Fortunately, the pathological species represent merely a fraction of the more than 1350 described species throughout the world (Kent et al. 2001).

In Africa more than 135 species of myxozoans are known to infect freshwater, brackish and marine fishes (Kostoïngue et al. 2001). Seven of these, representing two genera, have been described from Clarias Scopoli, 1777 species in Africa (Table 1). Henneguya clariae Abolarin, 1971 was the first species to be described from the gills of $C$. lazera in Nigeria by Abolarin (1971). This description also appears to be the first record of the genus Henneguya Thélohan, 1892 in Africa. Several years later Landsberg (1987) described H. laterocapsulata Landsberg, 1987 and H. suprabranchiae Landsberg, 1987 from the skin and suprabranchial organs, respectively, of the same host in
Israel. Ashmawy et al. (1989) described H. branchialis Ashmawy, Abu-Elwafa, Imam et El-Otifi, 1989 from the gills of C. lazera in Egypt. Some dispute has existed regarding the identification of this species and recently Ali (1999) suggested that $H$. branchialis is in fact a synonym of $H$. suprabranchiae. Myxobolus clarii Mandour, Galal et Abed, 1993 was described from the testis of C. lazera in Egypt by Mandour et al. (1993), afterwhich M. comoei Kabré, Sakiti, Marqués et Sawadago, 1995 was described from the gills of $C$. anguillaris Linnaeus, 1758 in Burkina Faso by Kabré et al. (1995). Most recently, Kostoïngue et al. (1999) described $H$. fusiformis Kostoïngue, Fall, Faye et Toguebaye, 1999 from the gills of C. anguillaris in Chad.

This paper presents preliminary results of the first investigation into myxozoan parasites infecting the sharptooth catfish, Clarias gariepinus in the Okavango River and Delta in Botswana. Two new species, Henneguya samochimensis $\mathrm{sp} . \mathrm{n}$. and Myxobolus gariepinus sp. n. are described, whilst $H$. suprabranchiae is recorded for the first time in southern Africa.

\section{MATERIALS AND METHODS}

Fourteen Clarias gariepinus specimens were captured and examined for the presence of myxozoan infections. During June and July (1998-2000) as well as in August 2001 fish were sampled using a series of gill nets from the lagoon environments within the Okavango River Panhandle and Delta regions in Botswana. Captured fish were killed using high concentrations of anaesthetic benzocaine $\left(2.5 \times 10^{-5} \mathrm{~g} / \mathrm{l}\right)$ (ethyl-4-aminobenzoate), and then identified using Skelton (1993), measured and examined for the presence of myxozoan 

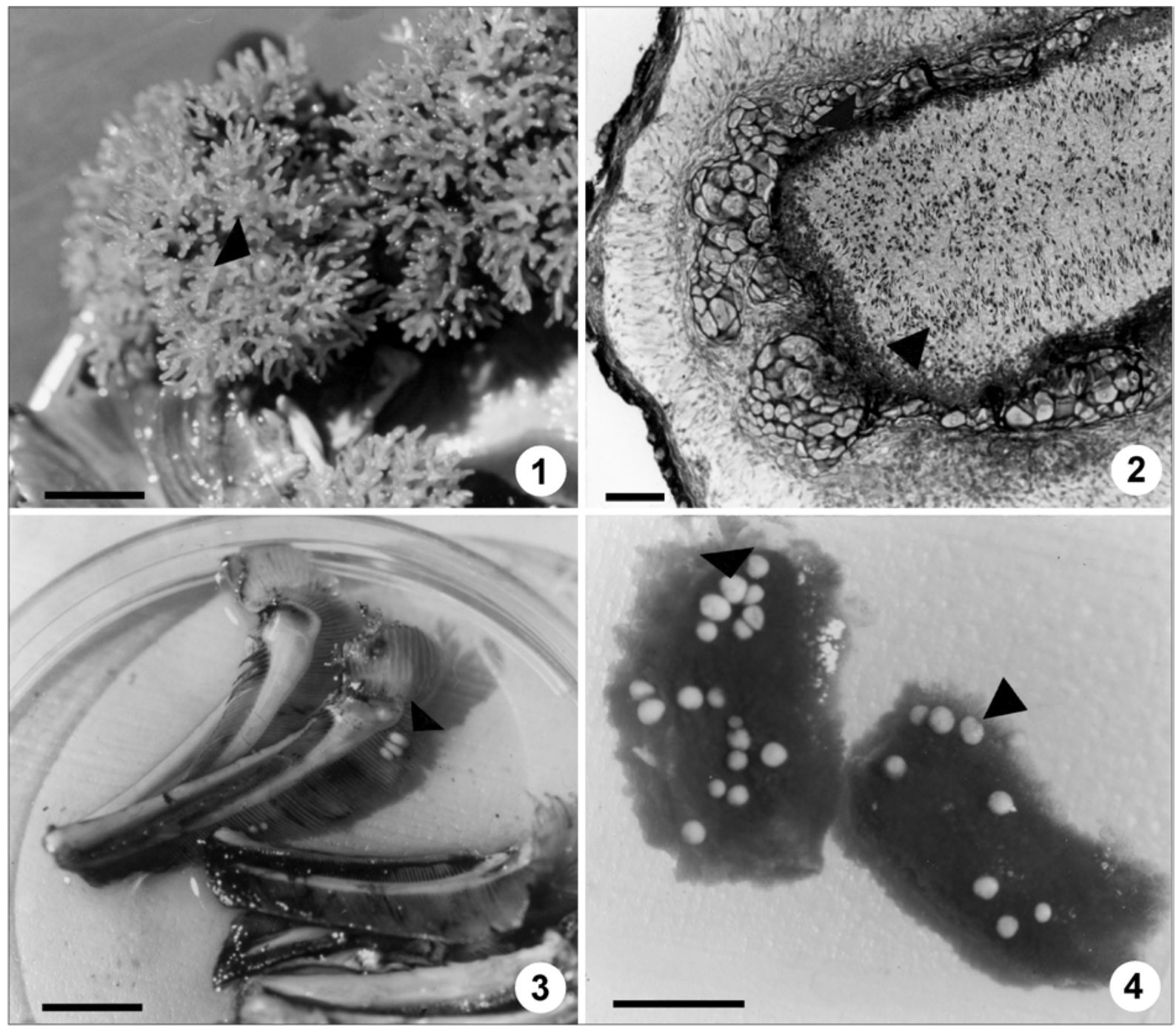

Figs. 1-4. Photographs of myxozoan infections in the organs of Clarias gariepinus from the Okavango River and Delta, Botswana. Fig. 1. Henneguya suprabranchiae Landsberg, 1987 plasmodia in the accessory breathing organ. Fig. 2. Histological section through infected accessory breathing organ showing displacement of cartilage by the large H. suprabranchiae plasmodia. Fig. 3. Henneguya samochimensis sp. n. plasmodia in the gills. Fig. 4. Myxobolus gariepinus sp. n. plasmodia in the ovaries. Scale bars: Figs. 1, 3, $4=1 \mathrm{~cm}$; Fig. $2=10 \mu \mathrm{m}$; arrowheads indicate position of plasmodia.

infections. Due to the remote collection localities, mature myxosporean spores found in plasmodia were fixed in $10 \%$ buffered neutral formalin and transported back to the laboratory in the Department of Zoology and Entomology at the University of the Free State, Bloemfontein. There they were photographed using an Axiophot microscope with differential interference contrast on a layer of $0.5 \%$ nonnutrient agar. Formalin-fixed spores were dehydrated through a series of ethanol concentrations, critical point dried in a Biorad critical point drier, coated with gold in an Emscope SC 500 sputter coater and viewed using a JEOL Winsem JSM 6400 at 5 or $10 \mathrm{kV}$. Formalin-fixed spores were measured according to the guidelines provided by Lom and Arthur (1989), with minimum and maximum values of spore measurements provided in micrometres $(\mu \mathrm{m})$, followed in parentheses by arithmetic mean and standard deviation. Tissue samples of organs containing plasmodia were fixed in Davidson's solution and prepared for histological sectioning using standard techniques. Sections were cut at $7 \mu \mathrm{m}$ and stained with standard Masson's Trichrome stain. All reference material, in the form of fixed spores or silver-impregnated smears of spores, has been deposited in the parasite collection of the Department of Zoology and Entomology, University of the Free State, Bloemfontein, South Africa where it has been allocated a reference number. Type material of the new species has been deposited in the collection of the National Museum, Bloemfontein (South Africa) where it has been allocated a NMBP number indicating its place in the National Museum Bloemfontein's Parasite collection. 

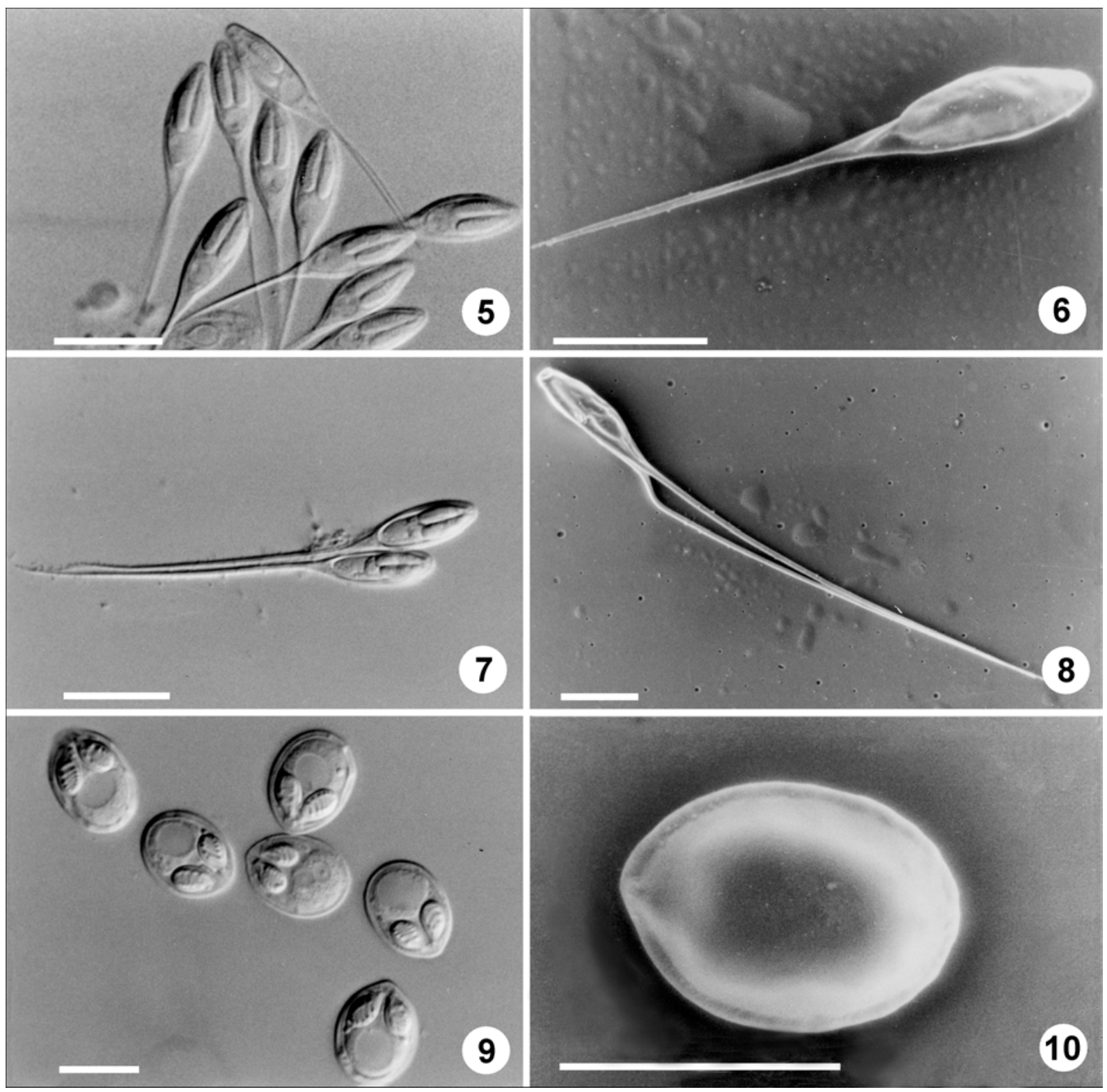

Figs. 5-10. Photomicrographs (Figs. 5, 7, 9) and scanning electron micrographs (Figs. 6, 8, 10) of formalin-fixed spores of myxozoans from the gills and ovaries of Clarias gariepinus from the Okavango River and Delta, Botswana. Figs. 5, 6. Henneguya suprabranchiae Landsberg, 1987. Figs. 7, 8. Henneguya samochimensis sp. n. Figs. 9, 10. Myxobolus gariepinus sp. n. Scale bars $=10 \mu \mathrm{m}$.

\section{RESULTS AND DISCUSSION}

An average of six Henneguya suprabranchiae plasmodia was found situated within the tips of cartilage in the accessory breathing organ of two of the 14 individual C. gariepinus collected. The second Henneguya species was found infecting the primary gill filaments of two C. gariepinus specimens, with one to four plasmodia situated in the primary gill lamellae of the infected individuals. Ovaries of three of the captured C. gariepinus were infected with plasmodia of the
Myxobolus species. In each case an average of 16 plasmodia were seen distributed throughout the ovaries.

\section{Henneguya suprabranchiae Landsberg, 1987}

Figs. 1, 2, 5, 6, 11

Description of vegetative stages. Sporogonic plasmodia found in cartilage at tips of suprabranchial respiratory organ. Polysporous plasmodia round, yellowish, 2-4 $\mathrm{mm}$ in diameter. 

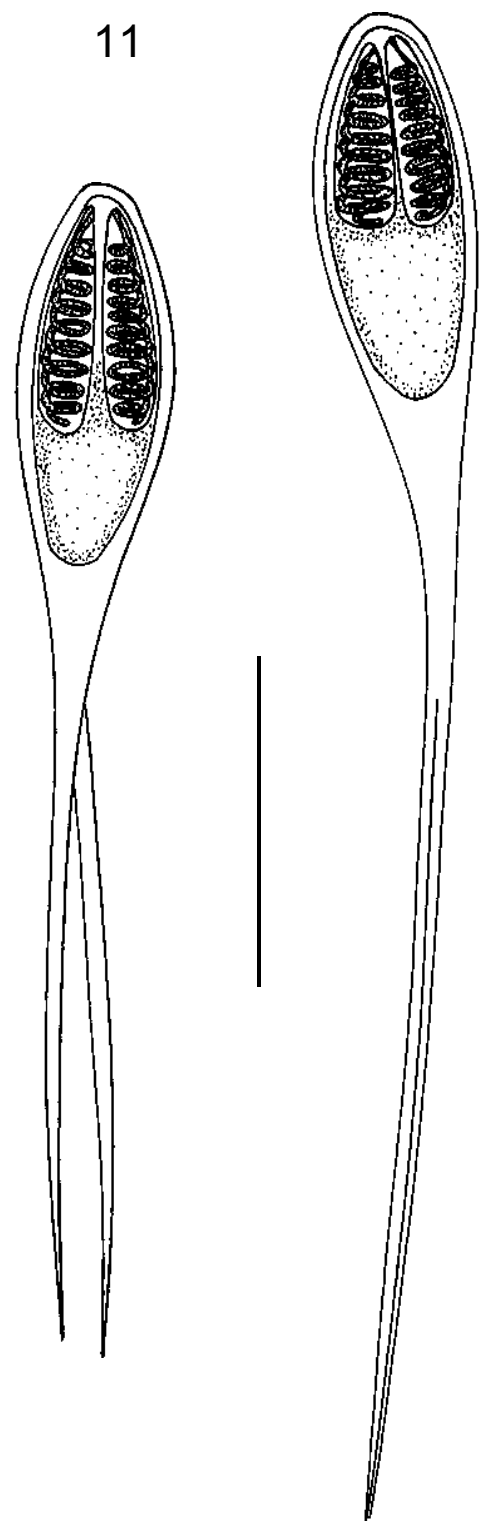

Figs. 11, 12. Myxozoans infecting Clarias gariepinus from the Okavango River and Delta, Botswana; microscope projection drawings of formalin-fixed spores. Fig. 11. Henneguya suprabranchiae Landsberg, 1987. Fig. 12. Henneguya samochimensis sp. n. Scale bar $=10 \mu \mathrm{m}$.

Description of spores (based on 10 formalin-fixed spores from fully mature plasmodia). Spore body elongated to fusiform in valvular view with anterior and posterior ends tapering to blunt points, 16.2-18.2 (17.2 \pm 0.5 ) long. Spore body prolonged by two filiform, thin extensions that are separated. Total length of spores 38.4-43.0 (40.4 \pm 1.9$)$. Caudal length 22.2-25.8 (23.2 \pm 1.4). Two elongated pyriform polar capsules situated at anterior end of spore lying parallel, $7.5(7.5 \pm 0)$ long $\times$ $1.9(1.9 \pm 0)$ wide. Widest region of spore is towards posterior ends of polar capsules measuring 5.0-6.3 (6.0 \pm 0.5 ). Polar capsules contain polar filaments with nine coils, filling almost two thirds of spore cavity. Two smooth shell valves visible, two filiform and long expansions clearly separated at base. Narrow sutural ridge visible surrounding spore body.

H o s t: Clarias gariepinus (Burchell, 1822) (Siluriformes: Clariidae).

S i t e of in fe c t i o n : Cartilage of the accessory breathing organ.

Prevale n c e : $14.3 \%(2 / 14)$.

L o c a 1 i t i e s : Samochima (18 $25^{\prime} 26.08^{\prime \prime}$ 'S $21^{\circ} 54^{\prime} 09.26^{\prime \prime}$ 'E) and Duba (18'58'27.78'S; 22³3'44.22”'E) Lagoons, Okavango River and Delta, Botswana.

M a t e rial ex a m in ed:1999/07/04-13 (spores fixed in $10 \%$ buffered neutral formalin).

Remarks. The morphology and measurements of the myxozoan spores found in mature plasmodia at the tips of the accessory breathing organ of $C$. gariepinus conform to the description of Henneguya suprabranchiae. This myxosporean species was originally described from the accessory breathing organ of the same host in Israel by Landsberg (1987). As illustrated in Fig. 2, it appears as if the infection may also result in replacement of the cartilaginous tissue in the accessory breathing organ. El-Mansy and Bashtar (2002) found that mass growth of the plasmodium of $H$. suprabranchiae in this organ led to pressure on the host cartilaginous tissue which was subsequently compressed. This is the first record of $H$. suprabranchiae in the Okavango River and Delta in Botswana.

Henneguya samochimensis sp. n. Figs. 3, 7, 8, 12

Description of vegetative stages. One to four large, oval to oblong, mature sporogonic plasmodia found extending into primary gill filaments. Polysporous plasmodia, yellow to whitish, $2-5 \mathrm{~mm}$ in length.

Description of spores (based on 10 formalin-fixed spores from mature plasmodia). Mature spore body elongated to oval in valvular view with bluntly pointed narrow anterior end, $12.3-15.0(13.7 \pm 0.8)$. Posterior end narrowly rounded. Spore body, prolonged by two very filiform, narrow and long extensions, total length 47.0-53.0 (50.3 \pm 4.5$)$. Caudal appendages separated from each other, 34.7-35.3 (36.6 \pm 3.7$)$ long. Two pyriform to straight polar capsules visible in anterior part of spore. Polar capsules nearly parallel to each other, filling just less than half of spore body cavity $5.0-6.0$ $(5.6 \pm 0.6)$ long $\times 1.3-1.9(1.6 \pm 0.3)$ wide. Widest part of spore found towards posterior ends of polar capsules, measuring 5.0-7.0 $(6.0 \pm 0.6)$. Polar capsules contain eight coils in the polar filament. Two smooth shell valves visible that extend into two filiform projections. Narrow sutural ridge visible.

$\mathrm{T}$ y p e $\mathrm{h}$ o s t : Clarias gariepinus (Burchell, 1822) (Siluriformes: Clariidae).

T y p e 1 o c a 1 i t y : Samochima Lagoon (18²5'26.08”'S; 21 $\left.{ }^{\circ} 54^{\prime} 09.26^{\prime \prime} \mathrm{E}\right)$, Okavango River, Botswana.

$\mathrm{S}$ it e of infection: Primary gill lamellae. 
Prevale n c e: $14.3 \%(2 / 14)$.

E t y m o lo g y : Named after the type locality.

M a t e r i a 1 : Syntypes; spores in $10 \%$ neutral buffered formalin, 2000/08/12-03 (NMBP 276); spores in 10\% neutral buffered formalin, 1999/07/02-33 (NMBP 277) and 1999/07/02-01 (NMBP 278); in the collection of the National Museum, Bloemfontein, South Africa.

Remarks. Significant differences can be seen when comparing the morphology and spore measurements of $H$. samochimensis to that of the other African Henneguya species parasitizing Clarias hosts (Table 2). Henneguya samochimensis differs from $H$. clariae, which has fused caudal appendages (Abolarin 1971) and a much longer total spore length (Table 2). The shape of the spore body of $H$. clariae has an almost sharply pointed anterior end with two unequally-sized polar capsules. Henneguya samochimensis differs significantly from $H$. fusiformis since the latter species has a fusiform spore body that contains two polar capsules with one situated behind the other (Kostoïngue et al. 1999). Henneguya samochimensis is also distinct from $H$. laterocapsulata in having two polar capsules both positioned next to each other in the anterior of the spore and not having one polar capsule that discharges laterally as in the case of the latter. The caudal appendages of $H$. laterocapsulata extend from a thick caudal base (Landsberg 1987), which is absent in H. samochimensis. Furthermore, the caudal appendages of $H$. laterocapsulata are also thick and divergent, curving outwards half way along their length. This is distinctly different from the thin filiform caudal appendages of $H$. samochimensis. Compared to $H$. suprabranchiae, $H$. samochimensis has a much longer average total spore length, whilst the polar capsules of $H$. samochimensis are proportionally smaller than those of $H$. suprabranchiae (Table 2). Morphologically $H$. samochimensis resembles $H$. bopeleti Fomena et Bouix, 1987 described from Chrysichthys nigrodigitatus in Cameroon by Fomena and Bouix (1987). The spore body length of $H$. samochimensis is, however, shorter, and the total spore length is longer than that of $H$. bopeleti. Another morphologically similar species is Henneguya nyongensis Fomena et Bouix, 1996, found in the gills of Marcusenius moori in Chad by the same authors (Fomena and Bouix 1996), but is distinguished from $H$. samochimensis in having very characteristic 'neck-like' appearances at the anterior ends of the polar capsules.

\section{Myxobolus gariepinus sp. n.}

Figs. 4, 9, 10, 13

Description of vegetative stages. Sporogonic plasmodia found in ovaries. Polysporous plasmodia spherical, whitish, 2-3 $\mathrm{mm}$ in diameter.

Description of spores (based on 10 formalin-fixed spores from fully mature plasmodia). In valvular view, spore body ovoid to spherical with anterior end bluntly rounded, 13.7-15.0 $(13.9 \pm 0.4)$ long. Widest region of

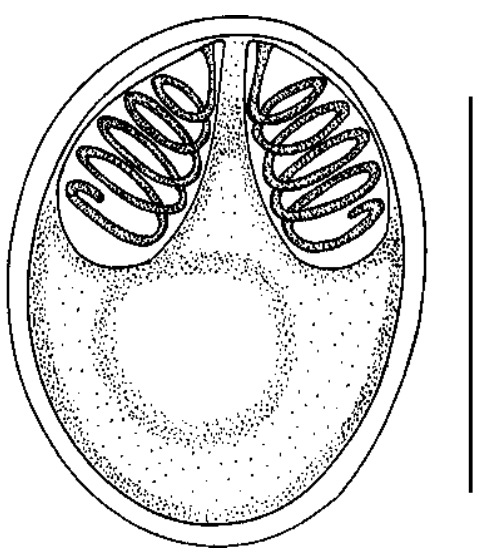

Fig. 13. Myxobolus gariepinus sp. n. infecting Clarias gariepinus from the Okavango River and Delta, Botswana; microscope projection drawing of formalin-fixed spore. Scale bar $=10 \mu \mathrm{m}$.

the spore observed towards posterior ends of polar capsules, measuring 10.0-11.2 (10.8 \pm 0.5$)$. Two smooth shell valves visible with two pyriform polar capsules of equal size converging in anterior part of spore, 6.0-6.2 $(6.2 \pm 0.1)$ long $\times 3.0-3.7(3.5 \pm 0.13)$ wide. Five to six coils of polar filament in polar capsules. Intercapsular process absent. Large iodinophilous vacuole present in sporoplasm.

$\mathrm{T}$ y p e $\mathrm{h}$ o s t : Clarias gariepinus (Burchell, 1822) (Siluriformes: Clariidae).

T y p e 1 o c a 1 i t y : Samochima Lagoon (18²5'26.08"S; 21 54'09.26”E), Okavango River, Botswana.

Site of infection: Ovaries.

Prevale n c e: $21 \%(3 / 14)$.

E t y m o l o g y : Species name derived from the type host.

M a t e r i a 1 : Syntypes; spores in 10\% neutral buffered formalin, 1999/07/02-39 (NMBP 279); spores in 10\% neutral buffered formalin, 1999/07/02-31 (NMBP 280) and 1999/02/02-02 (NMBP 281); in the collection of the National Museum, Bloemfontein, South Africa.

Remarks. Myxobolus gariepinus shows similarities to M. clarii Mandour, Galal et Abed, 1993 (Table 1), but differs in having a small blunt point, which appears to be absent in $M$. clarii. The overall shape of $M$. gariepinus also resembles $M$. comoei Kabré, Sakiti, Marqués et Sawadago, 1995 (Table 1) in having a similar almost spherical spore body, the latter species, however, has two polar capsules that take up about half the space in the spore cavity while the polar capsules of $M$. gariepinus only take up about one third of the spore cavity. The small blunt point at the anterior end of $M$. gariepinus is also absent in $M$. comoei. Other morphologically similar species include $M$. bilongi Fomena, Marqués, Bouix et Njiné, 1994, M. fotoi Fomena, Marqués et Bouix, 1993 and M. njinei Fomena, Bouix et Birgi, 1985. Firstly, M. gariepinus is distinct from M. bilongi, found in the gills of a Labeo sp. by 
Table 1. Myxozoan species from Clarias Scopoli, 1777 hosts in Africa and Israel.

\begin{tabular}{|c|c|c|c|c|}
\hline Species & Host & Organ & Country & Reference \\
\hline Henneguya branchialis $\#$ & C. lazera* & gills, intestine & Egypt & Ashmawy et al. (1989) \\
\hline H. clariae & C. lazera* & gills & Nigeria & Abolarin (1971) \\
\hline H. fusiformis & C. anguillaris & gills & Chad & Kostoïngue et al. (1999) \\
\hline H. laterocapsulata & $\begin{array}{l}\text { C. lazera } \times \\
\text { H. bidorsalis }\end{array}$ & skin & Israel & Landsberg (1987) \\
\hline H. samochimensis & C. gariepinus & gills & Botswana & present study \\
\hline H. suprabranchiae & C. lazera* & a.b.o. & Israel & Landsberg (1987) \\
\hline Myxobolus clarii & C. lazera* & testis & Egypt & Mandour et al. (1993) \\
\hline M. comoei & C. anguillaris & gills & Burkina Faso & Kabré et al. (1995) \\
\hline M. gariepinus & C. gariepinus & ovaries & Botswana & present study \\
\hline
\end{tabular}

a.b.o. - accessory breathing organ; \# - synonym of Henneguya suprabranchiae Landsberg, 1987; * - junior synonym of Clarias gariepinus (Burchell, 1822)

Table 2. Comparison of spore measurements (in $\mu \mathrm{m}$ ) of the myxosporean species previously described from Clarias Scopoli, 1777 hosts in Africa to those collected from C. gariepinus (Burchell, 1822) from the Okavango River and Delta in Botswana.

\begin{tabular}{|c|c|c|c|c|c|c|c|c|}
\hline \multirow{2}{*}{ Species } & \multirow{2}{*}{$\mathrm{Re}$} & \multirow{2}{*}{ STL } & \multirow{2}{*}{ SBL } & \multirow{2}{*}{ SBW } & \multirow{2}{*}{$\mathrm{CL}$} & \multicolumn{2}{|c|}{$\mathrm{PC}$} & \multirow{2}{*}{$\begin{array}{l}\text { No. } \\
\text { coils }\end{array}$} \\
\hline & & & & & & $\mathrm{L}$ & W & \\
\hline $\begin{array}{l}\text { Henneguya } \\
\text { branchialis } \#\end{array}$ & 1 & $\begin{array}{c}28.4-41.1 \\
\quad(34.4)\end{array}$ & $\begin{array}{c}12.7-17.6 \\
(14.7)\end{array}$ & $\begin{array}{l}4.4-6.4 \\
(5.0)\end{array}$ & $15.5-23.5$ & $\begin{array}{l}5.9-8.3 \\
(6.9)\end{array}$ & $\begin{array}{c}1.5-2.9 \\
(2.1)\end{array}$ & $\mathrm{n} / \mathrm{p}$ \\
\hline H. clariae & 2 & $\begin{array}{l}45.0- \\
107.5 \\
(88.0)\end{array}$ & $\begin{array}{l}17.5-28.5 \\
(22.0)\end{array}$ & $\begin{array}{l}5.5-8.5 \\
(6.5)\end{array}$ & $\begin{array}{l}27.5-89.0 \\
\quad(66.0)\end{array}$ & $\begin{array}{l}5.0-12.0^{*} \\
5.5-13.5^{* *}\end{array}$ & $\begin{array}{l}2.5-3.0^{*} \\
3.0-3.5^{* *}\end{array}$ & $\mathrm{n} / \mathrm{p}$ \\
\hline H. fusiformis & 3 & $59.0-61.0$ & $29.0-33.0$ & $5.0-7.0$ & $\begin{array}{c}28.0-31.0 \\
\quad(30.0)\end{array}$ & $5.0-6.0$ & $3.0-4.0$ & $\mathrm{n} / \mathrm{p}$ \\
\hline H. laterocapsulata & 4 & $\begin{array}{l}29.0-36.2 \\
\quad(32.7)\end{array}$ & $\begin{array}{l}13.8-16.0 \\
(14.7)\end{array}$ & $\begin{array}{c}3.7-5.3 \\
(4.3)\end{array}$ & $\begin{array}{c}15.2-20.2 \\
(18.0)\end{array}$ & $\begin{array}{c}4.1-5.3 \\
(4.3)\end{array}$ & $\begin{array}{l}2.2-3.0 \\
(2.6)\end{array}$ & $5-6$ \\
\hline $\begin{array}{l}\text { H. samochimensis } \\
\text { (present study) }\end{array}$ & $\mathrm{P}$ & $\begin{array}{l}47.0-53.0 \\
\quad(50.3)\end{array}$ & $\begin{array}{c}12.3-15.0 \\
(13.7)\end{array}$ & $\begin{array}{c}5.0-7.0 \\
(6.0)\end{array}$ & $\begin{array}{c}34.7-35.3 \\
(36.6)\end{array}$ & $\begin{array}{l}5.0-6.0 \\
(5.6)\end{array}$ & $\begin{array}{c}1.3-1.9 \\
(1.9)\end{array}$ & 8 \\
\hline H. suprabranchiae & 5 & $\begin{array}{c}30.7-43.3 \\
(37.5)\end{array}$ & $\begin{array}{c}12.2-14.3 \\
(13.5)\end{array}$ & $\begin{array}{c}5.6-6.9 \\
(6.4)\end{array}$ & $\begin{array}{c}18.5-29.0 \\
(24.0)\end{array}$ & $\begin{array}{l}7.0-8.1 \\
(7.6)\end{array}$ & $\begin{array}{l}1.8-2.3 \\
(2.1)\end{array}$ & $9-10$ \\
\hline $\begin{array}{l}\text { H. suprabranchiae } \\
\text { (present study) }\end{array}$ & $\mathrm{P}$ & $\begin{array}{c}38.4-43.0 \\
\quad(40.4)\end{array}$ & $\begin{array}{c}16.2-18.2 \\
(17.2)\end{array}$ & $\begin{array}{c}5.0-6.3 \\
(6.0)\end{array}$ & $\begin{array}{c}22.2-25.8 \\
(23.2)\end{array}$ & 7.5 & 1.9 & 9 \\
\hline Myxobolus clarii & 6 & $\mathrm{n} / \mathrm{a}$ & $9.0-12.0$ & $7.5-10.0$ & $\mathrm{n} / \mathrm{a}$ & $3.5-5.0$ & $2.0-2.5$ & $\mathrm{n} / \mathrm{p}$ \\
\hline M. comoei & 7 & $\mathrm{n} / \mathrm{a}$ & $10.0-12.0$ & $8.0-9.0$ & $\mathrm{n} / \mathrm{a}$ & $4.0-5.0$ & $2.5-3.0$ & $\mathrm{n} / \mathrm{p}$ \\
\hline $\begin{array}{l}\text { M. gariepinus } \\
\text { (present study) }\end{array}$ & $\mathrm{P}$ & $\mathrm{n} / \mathrm{a}$ & $\begin{array}{c}13.7-15 \\
(13.9)\end{array}$ & $\begin{array}{l}10.0-11.2 \\
(10.8)\end{array}$ & $\mathrm{n} / \mathrm{a}$ & $\begin{array}{c}6.0-6.2 \\
(6.2)\end{array}$ & $\begin{array}{c}3.0-3.7 \\
(3.5)\end{array}$ & $5-6$ \\
\hline
\end{tabular}

$\mathrm{CL}$ - caudal process length; $\mathrm{L}$ - length; $\mathrm{n} / \mathrm{a}$ - not applicable; $\mathrm{n} / \mathrm{p}$ - not provided by original authors; $\mathrm{P}$ - present study; $\mathrm{PC}$ - polar capsule; Re - reference; SBL - spore body length; SBW - spore body width; STL - spore total length; W - width; 1 - Ashmawy et al. (1989); 2 - Abolarin (1971); 3 - Kostoïngue et al. (1999); 4 - Landsberg (1987); 5 - Mandour et al. (1993); 6 - Kabré et al. (1995); * - shorter polar capsule; ** - longer polar capsule; \# - synonym of Henneguya suprabranchiae Landsberg, 1987

Fomena et al. (1994), since the latter myxosporean possesses two polar capsules of unequal sizes. Myxobolus gariepinus differs from $M$. fotoi since the latter has an almost completely spherical spore and also according to Fomena et al. (1993) has polar capsules that are subspherical and take up approximately one fourth of the spore cavity. Myxobolus njinei, a parasite of various Barbus species (Fomena et al. 1994), has a much larger and more oval spores, with two distinctly unequally sized polar capsules taking up almost two thirds of the spore body (Fomena et al. 1985), differing from the more spherical spore body of $M$. gariepinus.

Acknowledgements. This study was funded by the Debswana Diamond Company, Botswana and the National Research Foundation (NRF) of South Africa. We would also like to thank the Canon Collins Trust for Southern African Education for additional funding and Prof. Angela Davies (Kingston University, UK) and Prof. Iva Dyková (Institute of Parasitology, Czech Republic) for their valuable assistance and scientific input. 


\section{REFERENCES}

ABOLARIN M.O. 1971: A new species of Henneguya (Myxosporida, Protozoa) from West African Catfish, Clarias lazera Val. with a review of the genus Henneguya Thélohan, 1892. Afr. J. Trop. Hydrobiol. Fish. 1: 93-105.

ALI A.A. 1999: Henneguya ghaffari sp. n. (Myxozoa: Myxosporea), infecting the Nile perch Lates niloticus (Teleostei: Centropomidae). Dis. Aquat. Org. 38: 225-230.

ASHMAWY K.I., ABU-ELWAFA S.A., IMAM E.A., ELOTIFI Y.Z. 1989: Description of newly recorded myxosporidian protozoa of freshwater fishes in Behera Province, Egypt. J. Egypt. Vet. Med. Assoc. 49: 43-53.

EL-MANSY A., BASHTAR A.-R. 2002: Histopathological and ultrastructural studies of Henneguya suprabranchiae Landsberg, 1987 (Myxosporea: Myxobolidae) parasitizing the suprabranchial organ of the freshwater catfish Clarias gariepinus Burchell, 1822 in Egypt. Parasitol. Res. 88: 617-626.

FOMENA A., BOUIX G. 1987: Contribution á l'étude des Myxosporidies des poissons d'eau douce du Cameroun. III. Espèces nouvelles des genres Henneguya Thélohan, 1892 et Thelohanellus Kudo, 1933. Rev. Zool. Afr. 101: 43-53.

FOMENA A., BOUIX G. 1996: New species of Henneguya Thélohan, 1892 (Myxozoa: Myxosporea) parasites of freshwater fishes in Cameroon. J. Afr. Zool. 110: 413423.

FOMENA A., BOUIX G., BIRGI É. 1985: Contribution à l'étude des Myxosporidies des poissons d'eau du Cameroun. II. Espéces nouvelles du genre Myxobolus Bütschli, 1882. Bull. Inst. Fond. Afr. Noire, Sér A. 46:1-2.

FOMENA A., MARQUÉS A., BOUIX G. 1993: Myxosporidea (Myxozoa) of Oreochromis niloticus (Linnaeus 1757) (Teleoste Cichlidae) in fish farming pools at Melen (Yaounde, Cameroon, Central Africa). J. Afr. Zool. 107: 45-56.

FOMENA A., MARQUÉS A., BOUIX G., NJINÉ T. 1994: Myxobolus bilongi n. sp., Thelohanellus assambai n. sp., T. sanagaensis n. $\mathrm{sp}$., Myxosporidies parasites de Labeo sp. (Téléostéen, Cyprinidae) du bassin de la Sanaga au
Cameroon (Afrique Centrale). Ann. Fac. Sci. Cameroun 1: 31-42.

KABRÉ G.B., SAKITI N.G., MARQUÉS A., SAWADAGO L. 1995: Myxobolus comoei n. sp. et Myxobolus burkinei n. sp., nouvelles Myxosporidies histozoîques chez Clarias anguillaris et Labeo coubie capturés dans les pêcheries au Burkina Faso (Afrique de 1'Ouest). Bull. Inst. Fond. Afr. Noire, Sér A. 48: 49-55.

KENT M.L., ANDREE K.B., BARTHOLOMEW J.L., ELMATBOULI M., DESSER S.S., DEVLIN R.H., FEIST S.W., HEDRICK R.P., HOFFMANN R.W., KHATTRA J., HALLETT S.L., LESTER R.J.G., LONGSHAW M., PALENZUELA O., SIDDALL M.E., XIAO C.X. 2001: Recent advances in our knowledge of the Myxozoa. J. Eukaryot. Microbiol. 48: 395-413.

KOSTOÏNGUE B., FALL M., FAYE N., TOGUEBAYE S. 1999: Three new myxosporidian (Myxozoa: Myxosporea) parasites of freshwater fishes from Chad (Central Africa). Acta Protozool. 38: 323-326.

KOSTOÏNGUE B., DIEBAKATE C., FAYE N., TOGUEBAYE S. 2001: Presence of Myxosporidea (Myxozoa: Myxosporea) of the genus Henneguya Thélohan, 1892 in freshwater fishes from Chad (Central Africa). Acta Protozool. 40: 117-123.

LANDSBERG J.H. 1987: Myxosporean parasites of the catfish Clarias lazera (Valenciennes). Syst. Parasitol. 9: 73-81.

LOM J., ARTHUR J.R. 1989: A guideline for the preparation of species descriptions in Myxosporea. J. Fish Dis. 12: 151-156.

MANDOUR A.M., GALAL A.A., ABED G.H. 1993: Myxobolus clarii n. sp. in the testis of the fish Clarias lazera from the river Nile of Assiut. Assiut Vet. Med. J. 29: 109-115.

SKELTON P. 1993: A Complete Guide to the Freshwater Fishes of Southern Africa. Southern Book Publishers, Halfway House, 388 pp.

SKELTON P., TEUGELS G.G. 1992: Neotype description for the African catfish Clarias gariepinus (Burchell, 1882) (Pisces: Siluroidei: Clariidae). Ichthyol. Bull. 56: 1-7.

Accepted 17 March 2003 